\title{
"ENTÃO ME CLASSIFICAVAM COMO ESTRANHO": ENTRE NARRATIVAS NA CONSTRUÇÃO DO ESTRANHO NO CORPO DE PROFESSORES GAYS
}

- PEDRO PAULO SOUZA RIOS

Universidade Federal de Sergipe

ALFRANCIO FERREIRA DIAS

Universidade Federal de Sergipe

Este trabalho tem como objetivo discutir os modos de construção do "estranho", no corpo e no discurso de professores gays, no semiárido baiano, tendo em vista os processos de construção de gênero e sexualidade, em suas trajetórias de vida, formação acadêmica e exercício profissional. Para tanto, desde uma metodologia qualitativa, centrada na análise de narrativas (auto)biográficas, perspectivamos as narrativas produzidas por seis professores gays egressos dos cursos de licenciatura da Universidade do Estado da Bahia - UNEB, Campus VII. O trabalho analítico realizado, recorrendo também à narrativa literária naturalista de Adolfo Caminha, em Bom-Crioulo, publicado em 1895, nos possibilitou inferir que os processos de produção do "estranho" agem sobre os corpos dos participantes da pesquisa desde a mais tenra idade, através de mecanismos de vigilância e punição em funcionamento, das distintas instituições reguladoras, dentre elas, a escola. Dessa forma, tornam-se salientes, nas narrativas, as estratégias de sobrevivência criadas por eles com vistas ao enfrentamento do modelo heteronormativo, estabelecido como norma única de vivência das sexualidades e das subjetividades de gênero, de modo a produzir, sob o signo do "estranho", tudo o que, em alguma medida, desafia esse modelo.

Palavras-chave: (Auto)biografias. Gênero. Homossexualidades. Trabalho docente. \\ "THEN I WAS CLASSIFIED AS A STRANGE PERSON": \\ BETWEEN NARRATIVES IN THE CONSTRUCTION OF THE STRANGE IN THE BODY OF GAY PROFESSORS}

The objective of this work is to discuss the ways of constructing the "strange" in the body and discourse of gay teachers in the Semi-ar- 
id Site of Bahia, considering the processes of gender and sexuality construction in their life trajectories, academic training and professional practice .Therefore, from a qualitative methodology centered on the analysis of (auto) biographical narratives, we approached the narratives produced by six gay professors graduated from the undergraduate courses of the State University of Bahia - UNEB, Campus VII. The analytical work, also using the naturalistic literary narrative of Adolfo Caminha, in "Bom-Crioulo" published in 1895, allowed us to infer on how the processes of production of the "strange" act on the bodies of the participants of the research from the earliest age, through vigilance mechanism and punishment in operation in the different regulatory institutions, among them, the school. In this way, the strategies of survival created by them with a view to confronting a heteronormative model, established as a single norm of experience of sexualities and of gender subjectivities, in order to produce under the sign of the "strange" everything which, to some extent, challenges this model.

Keywords: (Auto)biographies. Gender. Homosexuality. Teaching work.

\section{"ENTONCES ME CLASIFICAN COMO EXTRAÑO": ENTRE NARRATIVAS EN LA CONSTRUCCIÓN DEL EXTRANJERO EN EL CUERPO DE PROFESORES GAYS}

Este trabajo tiene como objetivo discutir los modos de construcción del "extraño" en el cuerpo y en el discurso de profesores gays en el Semiárido Baiano, teniendo en vista los procesos de construcción de género y sexualidad en sus trayectorias de vida, formación académica y ejercicio profesional. Para tanto, desde una metodología cualitativa centrada en el análisis de narrativas (auto)biográficas, contemplamos las narrativas producidas por seis profesores gays egresados de los cursos de licenciatura de la Universidad del Estado de Bahía - UNEB, Campus VII. El trabajo analítico realizado, recurriendo también a la narrativa literaria naturalista de Adolfo Caminha, en “Bom-Crioulo", publicado en 1895, nos posibilitó inferir los procesos de producción del "extraño" actúan sobre los cuerpos de los participantes de la investigación desde la más tierna edad, a través de mecanismos de vigilancia y punición en funcionamiento en las distintas instituciones reguladoras, entre ellas, la escuela. De esta forma, se destacan en las narrativas las estrategias de supervivencia creadas por ellos con vistas al enfrentamiento de modelo heteronormativo, establecido como norma única de vivencia de las sexualidades y de las subje- 
tividades de género, para producir bajo el signo del "extraño" todo que, en alguna medida, desafía ese modelo.

Palabras clave: (Auto)biografias. Género. La homosexualidad. Trabajo docente.

\section{Introdução}

Refletir acerca das homossexualidades, enquanto conceito historicamente construído, configura-se numa estratégia de resistência às tentativas intransigentes de barreiras entre as práticas sexuais, favorecendo a construção de uma transformação temática considerável, no campo dos estudos de gênero e sexualidades. Nesse sentido, as regulações de gênero não se constituem meramente em mais um arquétipo das formas de regulamentação de um poder mais extenso, mas se configuram enquanto modalidades de regulação próprias que têm finalidades específicas sobre a subjetividade (BUTLER, 2014). Assim, as regras que governam a identidade inteligivel são parcialmente estruturadas a partir de uma matriz que estabelece a um só tempo uma hierarquia entre masculino e feminino e uma heterossexualidade compulsória.

As narrativas acerca da homossexualidade estão presentes desde o início da escrita de diferentes grupos humanos. Distintas culturas, mitos, lendas, folclores e textos sagrados vinculados a diferentes religiões têm assimilado temas homoeróticos, de sexualidade e de gênero (GAMSON, 2007). Dessa maneira, é possível dizer que desde os tempos mais remotos mitos narravam estórias envolvendo homossexualidade, bissexualidade ou transexualidade, como símbolos de experiências míticas e/ou sagradas.

Com o intuito de produzir saberes a respeito da sexualidade, social e culturalmente, foram criados mecanismos para classificar, separar e nomear cada pessoa a partir de certas maneiras de se relacionar. Tendo por base esses mesmos procedimentos, estabeleceram normas e formas social e culturalmente aceitas para a vivência dos prazeres e dos desejos corporais e sexuais. Por esse ângulo, a homossexualidade foge dos parâmetros daquilo que é considerado normal, especialmente nas culturas judaico-cristãs, constituindo-se enquanto desvio, anormalidade, ou ainda, estranheza.

O sentimento de estranheza é acionado não pela sexualidade, mas pela diversidade de características utilizadas para dar sentido e atribuir identidades ao que se classifica de homossexual.

A rigor, discutir o estranho significa discorrer sobre uma espécie de não saber, de sua experiência propriamente dita. Para saber é preciso, primeiro, não saber. 0 estranho apresenta-se, pois, como um objeto que é capaz de brincar com a condição do sujeito pesquisador, que o desloca e que o faz por vezes o seu objeto. Esse objeto constitui uma categoria que não se deixa categorizar, que é estranha às suas classificações, refratária à posse.

Dessa forma, se constituiu objetivo desse estudo refletir acerca da construção do estranho nas trajetórias de seis professores gays egressos dos cursos de licenciatura da Universidade do Estado da Bahia - UNEB, Campus VIII. Esse estudo se configura enquanto pesquisa qualitativa e como método de pesquisa optamos pelas narrativas (auto)biográficas, por entender que as mesmas valorizam e exploram as dimensões pessoais dos sujeitos, seus afetos, sentimentos e trajetórias de vida, e levam à percepção da complexidade das interpretações que os sujeitos pesquisados fazem de suas experiências e ações, sucessos e fracassos, e dos problemas que enfrentam. 


\section{(Auto)biografia enquanto método em pesquisa qualitativa}

Compreendemos que a pesquisa de abordagem qualitativa é a que melhor atende aos objetivos propostos neste estudo. A pesquisa transitará entre os processos de estranhamento e subjetivação de gênero e sexualidade, a partir das narrativas (auto)biográficas das trajetórias de formação de professores gays, desenvolvendo-se em movimentos entrelaçados, na perspectiva das teorias pós-críticas, dos estudos queer e do método (auto)biográfico.

As teorias pós-críticas são as correntes identificadas com o pós-modernismo e o pós-estruturalismo e que primam por uma construção epistemológica distinta das perspectivas críticas, consolidando-se a partir da superação da concepção curricular crítica (SILVA, 2011; PARAíso, 2015). Enfatizam elementos vinculados às questões da cultura, relações de gênero, etnia, diferença e linguagem. Trata-se, portanto, de uma diversidade de pressupostos conceituais com o denominador comum da valorização da subjetividade, das relações sociais e da negação das metanarrativas.

Nesse estudo, a teoria queer articula-se à educação e às narrativas (auto)biográficas, para estudar a trajetória de vida e profissional de professores gays, atribuindo forma e sentido a questões que são particulares e comuns a eles, ao mesmo tempo em que convergem em outras vozes. Ao reconstituir aspectos da trajetória desses professores, ou "ao contar uma história, o narrador está se construindo e construindo o mundo à sua volta" (TILIO, 2003, p. 91).

As narrativas construídas através das trajetórias de vida estão presentes em todas as experiências humanas. Nas últimas décadas, teóricxs ${ }^{1}$ de diferentes áreas do conhecimento

1 Na escrita do texto, vamos optar pelo uso do " $x$ " por considerar que essa é "uma tentativa de, no âmbito da escrita, tornar a língua mais democrática, pois as distinções decorrentes do fato do gênero neutro ter as mesmas marcas morfológicas que o masculino, no têm se debruçado sobre memórias, experiências, narrativas e fatos para construir os sentidos da vida, tanto na esfera individual quanto coletiva de um determinado período e que, de alguma forma, confrontam e aproximam situações que são comuns a diferentes sociedades, contribuindo para que possamos aprender a lidar com essas narrativas.

Ao reconstituir aspectos da trajetória desses professores, ou ao contar uma história, o narrador está se construindo e construindo o mundo à sua volta (SOUZA, 2006). Dessa maneira, a partir da análise das narrativas de formação desses professores acorre um processo de autorreflexão sobre nossa formação e história de vida.

Contudo, suas revelações e seus sigilos, constituem-se em um material rico para a percepção dos conflitos a que esteve submetido aquelx que narra enquanto viveu e se formou ao longo da vida (JOSSO, 2010). Por meio das narrativas (auto)biográficas, podemos dizer que aquelx que narra produz a si mesmx, uma vez que o ato de narrar favorece a reflexão sobre os momentos vivenciados e suas próprias trajetórias, criando um ambiente de mudança através da própria reflexão. De acordo com Souza (2006, p. 95), o método (auto)biográfico contribui como parte das "experiências formadoras, as quais são perspectivas a partir daquilo que cada um viveu e vive, das simbolizações e subjetivações construídas ao longo da vida".

Dessa maneira, entendemos que as narrativas (auto)biográficas se constituem em importantes instrumentos de investigação acerca dos processos de formação de professorxs, uma vez que avultam questões relacionadas às subjetividades dos sujeitos, suas trajetórias de formação e experiências de vida, elementos que têm suscitado, cada vez mais, a averi-

caso da língua portuguesa, geram uma série de discussões e levam até a afirmações como "a língua é machista". (ROLOFF et al, 2015, p. 32) 
guação e a anuência de pesquisadorxs a estes métodos.

Quanto aos instrumentos metodológicos para a coleta de dados, optamos pela entrevista narrativa, que se configura enquanto atividade formadora e processo de formação e de conhecimento (SOUZA, 2006). Nesse sentido, a técnica de narrativas não só nos permite conhecer histórias individuais, mas nos possibilita conhecer a história de grupos e comunidades, uma vez que estrutura e ação se fazem presentes no momento em que a trajetória individual é reconstruída através da narração.

As entrevistas foram gravadas entre os dias 05 de agosto de 2018 e 11 de janeiro de 2019, em horários e lugares predefinidos, sempre respeitando a disponibilidade de tempo dos entrevistados. Antes do início da gravação, era feita uma breve explicação em torno do objeto deste estudo, sanando possiveis dúvidas dos entrevistados e deixando-os inteirados dos assuntos a serem tratados durante a entrevista. Em seguida, explicávamos o Termo de Livre Esclarecimento - TLE, solicitando a sua leitura e a assinatura do mesmo. Posteriormente, era elucidada a dinâmica da entrevista narrativa. Após esses esclarecimentos, a entrevista era iniciada.

Foram gravadas seis entrevistas, com diferentes colaboradores, com duração entre trinta e cinco minutos e uma hora cada uma delas. A gravação das narrativas era quase sempre envolta por distintos sentimentos. Cada história que se desvelava, no exato momento em que era pronunciado "estamos gravando", chegava até nós e era minuciosamente captada pelo gravador. Histórias únicas, imbuídas de vivências, marcadas por estranhamentos, superação, alegrias, tristezas, aprendizados, ensinamentos e, ao tempo que eram contadas, iam sendo re-visitadas e, por conseguinte, reinventadas.

Considerando a importância das expressões gestuais durante a gravação das entrevis- tas, fundamental no momento da transcrição e imprescindiveis para uma maior compreensão do conjunto das narrativas, foi relevante fazer um caderno de anotações, denominado de Narrativas Gestuais, no qual procuramos marcar o tempo exato em que gestos que compunham a narrativa eram expressados intencionalmente ou não. Tais anotações foram cuidadosamente consultadas no momento de transcrição das narrativas.

Narrar não é no fio da memória, mas as experiências vivenciadas por aquelx que narra. Narrar é a própria vida que vai sendo desvelada e re-tecida no tear cotidiano, é a experiência vivenciada sofrendo metamorfoses. De acordo com Benjamim (2009, p. 21), a narrativa é um ato de comprometimento individual e social daquelx que narra suas experiências e, assim sendo, toda narrativa está suscetível a ondulações, uma vez que ao narrar tais experiências a pessoa recorre "à máscara do adulto", objetivando uma narrativa seletiva, de acordo com aquelx que escuta.

Por isso, faz-se necessário estar atento para que a narrativa corresponda à palavra e a palavra à experiência, uma vez que, ao contar o que foi vivenciado a outrem, esse processo deixa de ser algo de cunho individual e, portanto, da memória subjetiva, passando a ser de cunho social, compondo uma narrativa coletiva.

No que se refere aos personagens deste estudo, é pertinente ressaltar, em primeiro lugar, que prezamos por diferentes experiências no tocante ao campo de atuação profissional, dessa maneira temos professorxs que trabaIham na Educação Básica e/ou Ensino Superior. Além disso, vale dizer que o contato inicial com estxs foi estabelecido inicialmente nas reuniões do Grupo de Estudos em Gênero e Sexualidades Sertanejas - GENESES-Sertaneja, ${ }^{2}$

2 Grupo de Estudos e Pesquisa em Educação, Gênero e Sexualidades, fundado em 2016. Vinculado à Universidade do Estado da Bahia - UNEB, Campus VII. 
mas durante o processo da pesquisa sentimos a necessidade de buscar outros personagens, considerando o fato de que a maioria dos participantes do GENESES-Sertaneja, no momento de definição dos personagens e da escuta, não estava em sala de aula, inviabilizando sua participação no estudo em curso, em face de seus objetivos.

Num primeiro momento, elencamos uma lista com seis possiveis personagens, chegando a mais de trinta possiveis narradores. Passamos então a entrar em contato, após termos definido os seguintes critérios: estar exercendo a docência e ter interesse em colaborar com o estudo em questão, uma vez que o “[...] narrador retira da experiência o que ele conta [...]" (BENJAMIN, 2009, p. 201), sendo, portanto, essas experiências, a base de todx narradxr. Assim, as experiências vivenciadas pelos professores, personagens desta investigação, vão se entrelaçar a diferentes momentos da vida pessoal e da formação profissional.

No que se refere ao direito ao anonimato dos personagens colaboradores da pesquisa, consideramos pertinentes preservá-lo, optando pela escolha de codinomes relacionados à mitologia africana, por entendermos que, historicamente, assim como gays, as divindades africanas têm sido classificas como estranhas. Os codinomes foram escolhidos durante o processo de digitação das narrativas, procurando elementos similares entre as trajetórias e a divindade africana. Assim, a presente narrativa foi construída por meio das tessituras de Logun Edé, Obá, Oxumaré, Oxóssi, lansã e Ossayn. Consideramos pertinente ressaltar que todas essas entidades, no Candomblé, estão associadas às experiências da sexualidade por serem vistas enquanto homossexuais, transexuais ou bissexuais.

Logun Edé é artista e professor. Atua na Educação Básica em um município há 171 km de Senhor do Bonfim. Tem 30 anos, é licenciado em Pedagogia e está cursando mestrado profissional em Extensão Rural, “[...] além dessas informações burocráticas, me considero uma pessoa com os pés no mundo, com os pés no chão desse mundo, que busca a partir da arte ressignificar muitas coisas". Além disso, Logun Edé, relatou ser gay e não recorda de ter tido outras experiências afetivas/sexuais que não fossem com homens, conforme sinaliza: “[...] não lembro ter sido outra coisa se não gay; no que se refere à sexualidade, sempre me reconheci gay".

Ossayn tem 36 anos, é professor de Biologia da rede pública estadual e está fazendo mestrado em Botânica. É gay, feliz e “[...] realizado profissionalmente, muito realizado profissionalmente". Conforme afirma, "não tenho como não me apresentar dizendo que sou gay, realizado e feliz. [...]. Então eu diria que é isso: um cara feliz, bom profissional e gay". Ossayn mora há 45 km de Senhor do Bonfim e estuda na Universidade Estadual de Feira de Santana - UEFS.

Oxumaré, 45 anos, é licenciado em Ciências com Habilitação em Matemática e desde muito cedo sabia que seria professor, o que o motivou a investir na formação docente. Outra característica de Oxumaré é sua a experiência em gestão, sempre associada à docência, conforme nos narrou. Ele diz: "durante muito tempo fui diretor de escola, fui diretor da DIREC $28^{3}$ e do NRE 28 durante dez anos e tudo isso atrelado à minha experiência com a docência, pois, mesmo estando na gestão, nunca deixei de dar aulas [...]", atuando na Educação Básica e no Ensino Superior, como docente do curso de Licenciatura em Matemática.

Oxóssi tem 39 anos, licenciado em Ciências com Habilitação em Matemática, fez especialização e mestrado em Matemática. Professor

3 As Diretorias Regionais de Educação - DIREC's eram coordenações regionais de ensino localizadas em polos regionais do Estado da Bahia, sendo substituídas, em 2015, pelos Núcleos Regionais de Educação - NRE. 
há mais de vinte anos, atualmente trabalha com Educação Básica e Ensino Superior no Instituto Federal de Ciência e Tecnologia Baiano - IFBAIANO. Anteriormente, foi docente na rede pública municipal e estadual de ensino, na UNEB, além de ter sido professor da Educação Básica, na rede privada. Conforme nos narrou, seu nome é muito forte, sendo motivo de brincadeira entre xs amigxs, ao afirmarem “[...] que Oxóssi é nome de homem. Por isso, quando falam que meu nome é Oxóssi, todos pensam que é homem másculo e quando olham é um gay. [...]".

Iansã tem 28 anos, é licenciado em Pedagogia. Está na docência há oito anos, onde atua como professor do Ensino Fundamental II em escolas públicas de Senhor do Bonfim. Antes de assumir a sala de aula, atuava como promotor cultural. Iansã nos contou: "antes eu passeava pela ideia de ser uma pessoa andrógena. Tinha época em que me vestia mais afeminada, já em outras épocas me recatava mais e me vestia mais masculino". Acerca de sua identidade, ele continua dizendo: "também considerado importante dizer que sou uma pessoa gay, agora trans e negra. Penso que ser negra e trans são duas coisas que marcam bastante. Como diz o povo: 'não bastou ser negro, tinha que ser viado"".

Obá, 39 anos, é graduado em Pedagogia, especialista em Psicanálise e está na docência há mais de dez anos. Atualmente, trabaIha com Educação Infantil. Obá também é ator e frequenta religião de matriz africana. Em relação a sua sexualidade, ele nos contou que, buscando negar sua homossexualidade, tentou viver como heterossexual, depois se reconheceu bissexual e agora se reconhece como gay.

Nosso intuito com essa apresentação não é fazer uma reflexão acerca daquilo que foi dito pelos personagens, mas antes fazer com que eles já sejam, em alguma medida, conhecidos, antes dos entrecruzamentos que faremos de suas trajetórias de vida e formação, no percurso analítico deste trabalho. Embora reconheçamos que uma breve apresentação não abarca a complexidade de suas identidades, apresentá-los pelo prisma dos modos como se autorreconhecem e suas experiências de estranheza, enquanto professores gays, uma vez que a (auto)biografia exprime o "escrito da própria vida" (JOSSO, 2010, p. 343), e nos ajuda a entender quem são, ao tempo em que nos possibilita maior compreensão de suas trajetórias de vida.

Diferente do depoimento, na narrativa (auto)biográfica, quem decide o que deve ou não ser contato é o ator, a partir da sua própria trajetória de vida, não necessariamente obedecendo a uma cronologia dos acontecimentos vivenciados pelo sujeito. Ainda que eu tenha direcionado a conversa, foi cada um dos personagens que determinou o "dizivel" da sua história, da sua subjetividade e dos percursos vivenciados ao logo de sua vida.

\section{A construção do estranho no corpo gay}

Compreender o estranho a partir das narrativas de professores gays constituiu-se objeto deste estudo, o que não se configurou numa tarefa óbvia, dada a pouca produção acadêmica científica acerca de tal termo. Dessa maneira, recorremos à literatura, por considerá-la um dos instrumentos de construção teóricometodológico de compreensão de distintas realidades, desde as mais perceptiveis às mais opacas. Velloso (1988) salienta que o texto literário possibilita maior compreensão a respeito da constituição de elementos da vida pessoal, social e intelectual, em determinados momentos históricos.

Bom-Crioulo, romance naturalista de Adolfo Caminha, publicado em 1895, não compôs a 
lista das obras literárias brasileiras indicadas para leitura, no período em que estudamos a Educação Básica. Além disso, em buscas feitas em plataformas digitais e sites - Mundo Vestibular e Mande Bem no ENEM, especializados na preparação para vestibulares e o Exame $\mathrm{Na}$ cional de Ensino Médio - ENEM, no período de 2010 a 2018, não encontramos nenhum indicativo da referia obra para leitura.

Não se constitui enquanto objetivo nosso fazer uma análise literária da obra, no entanto, entendemos que a mesma pode contribuir significativamente com nosso estudo, uma vez que a referida narrativa se aproxima das narrativas analisadas por nós neste estudo. Nesse sentido, uma primeira inferência que podemos fazer é considerar que é possivel que a ausência da obra nas listas de produções literárias indicadas para leitura seja decorrente do fato de que ela é considerada a primeira grande obra literária que tematiza a homossexualidade publicada no Brasil, em 1895.

Ademais, a referida obra foi ainda uma das primeiras a ter um personagem negro como herói. À época, Bom-Crioulo foi classificado como imoral por ser "o tema já de si abjeto, e tratado de modo que o torna extremamente chocante" (MIGUEL-PEREIRA, 1960, p. 9). Contrapondo-se a essa perspectiva, Trevisan (2009, p. 9) sinaliza que "[...] Bom Crioulo tornou-se o grande mito da literatura brasileira relacionada ao homoerotismo, pois nele aparece, pela primeira vez entre nós, um protagonista homossexual, dentro de uma relação homossexual também protagonística".

O personagem de Amaro, o bom crioulo da narrativa literária, é marcado pelas intersecções de raça, gênero e classe, próprias dos sujeitos do mundo que ele representa, os quais, quando contemplados pela literatura brasileira, era meramente para compor o proscênio sobre a diversidade, uma vez que competia a homens e mulheres brancxs, heterossexuais, de classe média, ocupar a cena central. Não por acaso, o romance, devido a seu caráter particular, desde a sua publicação, continua sendo motivo de grandes discussões.

É perceptível ainda, no início da narrativa literária em discussão, que, em meio à convivência interpessoal, marcadamente entre aqueles reconhecidos como homens, aquelxs consideradxs estranhxs em suas homossociabilidades interpessoais, são rotineiramente estereotipadxs pela atribuição de nomes depreciativos, além de serem excluídxs com xingamentos ou difamações específicas da masculinidade compulsória, pelos operários da Marinha, em Bom-Crioulo, constituindo-se em uma prática que atravessou os séculos, conforme sinalizou o professor lansã: “[...] ouvir difamações e xingamentos com o intuito de nos tornar inferiores já virou rotina. Às vezes elas vêm sútil, mas sempre vem".

O narrador da trama do livro de Adolfo Caminha (2010) sinaliza que a estranheza se dava por conta da sua homossexualidade. 0 fato de Amaro ser negro não era preponderante, uma vez que "Ali não se olhava a cor ou a raça do marinheiro: todos eram iguais, tinham as mesmas regalias - o mesmo serviço, a mesma folga" (2010, p. 40). É relevante ressaltar que Amaro era escravo fugido e trabalhava como marinheiro e que, portanto, a premissa de que "todos eram iguais" diz respeito a uma idealização.

Em relação à vivência da sua sexualidade, o autor relata suas tentativas fracassadas de manter relação com mulheres:

Sua memória registrava dois fatos apenas contra a pureza quase virginal de seus costumes, isso mesmo por uma eventualidade milagrosa: aos vintes anos, e sem pensar, fora obrigado a dormir com uma rapariga em Angra dos Reis, perto das cachoeiras, por sinal dera péssima cópia de si como homem; e, mais tarde, completamente embriagado, batera em casa de uma francesa no largo do Rocio, donde saíra 
envergonhadíssimo, jurando nunca mais se importar com 'essas coisas'. (CAMINHA, 2010, p. 34)

Nesse sentido, o professor Obá também narrou suas experiências com mulheres:

Então para entrar e ser aceito no universo masculino procurei uma namorada, isso na adolescência [...]. E só aos vinte e seis anos foi que me dei conta de que tudo aquilo estava acumulado dentro de mim e que eu precisava me libertar, já não suportava mais tanta dor, não eram dores fisicas, mas eram dores existenciais mesmo, eu precisava assumir quem eu era de fato ou acabaria me matando aos poucos. [...] Depois de um casamento de nove anos com uma mulher precisava deixar que essas coisas viessem à tona. Então entender a pessoa que eu sou, aceitar viver minha orientação sexual foi um processo muito dificil.

As experiências afetivo-sexuais de Amaro, o Bom-Crioulo, com mulheres, são descritas pelo olhar do narrador, que ao narrar acaba por torná-lo inferior aos demais, afirmando que "por sinal dera péssima cópia de si como homem" (CAMINHA, 2010, p. 38), possivelmente por não consumar o ato sexual com mulheres, tornando-o uma cópia ilegivel, estranha. Fato parecido vai acontecer com o professor Obá, ao narrar, ele mesmo, suas experiências com mulheres. Contou ele que "para entrar e ser aceito no universo masculino", procurou "uma namorada", mais à frente, em sua narrativa, ele contou que de "nada adiantava namorar com mulheres, pois todo mundo já suspeitava da sua orientação sexual", o que acabava por torná-lo classificável no tocante a sua homossexualidade, construindo-se, portanto, uma "péssima cópia" para as normas vigentes de gênero, a partir da masculinidade compulsória.

Após mais uma tentativa malsucedida com mulheres, de onde Amaro sai "envergonhadíssimo", ele jura "nunca mais se importar com essas coisas" (CAMINHA, 2010, p. 34). Experiência similar vai ocorrer com o professor Obá, ao nar- rar que chegou um momento em que não podia, não conseguia, não queria mais se enganar, nem enganar mais ninguém. "A melhor coisa a fazer, ainda que doesse, era assumir que é gay".

Em outro momento da narrativa, o professor Obá contou que se apaixonou por um homem e resolveu enfrentar "tudo e todos, inclusive a família", para viver esse relacionamento. Afirma ele: "[...] e da noite para o dia eu resolvo assumir que sou viado, então isso para a minha família foi um choque. Então me assumir, abertamente, enquanto gay, aos 26 anos, foi bafônico ${ }^{4}$ como dizem, mas eu precisava fazer isso, entende?"

Em Bom-Crioulo, Amaro também se apaixona por Aleixo, um jovem muito bonito, loiro, de olhos claros, assim que ele embarca no mesmo navio para trabalhar, garantindo proteção a ele, como preconiza: “Quando alguém o provocar, the fizer qualquer coisa, estou aqui, eu, para o defender, ouviu?" (CAMINHA, 2010, p. 30). É na embarcação que será consumada a primeira relação sexual entre os personagens. $O$ ato sexual foi narrado da seguinte maneira pelo narrador: "E consumou-se o delito contra a natureza" (CAMINHA, 2010, p. 43), evidenciando, portanto, sua estranheza perante uma cena homossexual classificada como "contra a natureza" e, portanto, fora da norma. Evidenciamos, assim, a fissura do que está entranhado social e culturalmente em relação ao binarismo sexual estabelecido.

A concepção binária, constituída social e culturalmente, é arbitrária e hierarquizante, uma vez que privilegia aqueles identificados como homens, os quais desempenham atributos de uma masculinidade compulsória e, em detrimento da subordinação da mulher e de tudo o que é classificado como feminino, estereotipa como estranhxs todxs aquelxs que

4 Termo utilizado entre pessoas LGBTQI para designar aquilo ou algo que é muito bom ou lindo. Aquilo, algo ou alguém que chama muita atenção. Uma notícia surpreendente. 
rompam as normas de gênero e sexualidade. A invisibilidade conferida à homossexualidade pode ser percebida, portanto, a partir dos discursos moralizantes, predominantes no meio social, os quais designam os gays e as lésbicas como portadores de uma conduta imoral e subversiva.

Sobre esse prisma o estranhamento é atribuído ao fato de não se enquadrar na lógica heteronormativa. Não obstante, encontrar-se ou reconhecer-se estranhx, em determinadas situações, pressupõe autoquestionar-se acerca da estranheza. Em Bom-Crioulo, Amaro questiona a sua orientação, atribuindo-lhe uma espécie de sentença, como se sua vivência da sexualidade fosse algo pecaminoso:

Ao pensar nisso Bom-Crioulo sentia uma febre extraordinária de erotismo, um delírio invencível de gozo pederasta... Agora compreendia que só no homem, no próprio homem, ele podia encontrar aquilo que debalde procurara nas mulheres. Nunca se apercebera de semelhante anomalia, nunca em sua vida tivera a lembrança de perscrutar suas tendências em matéria de sexualidade. [...] E o mais interessante é que aquilo ameaçava ir longe, para mal de seus pecados... Não havia jeito, senão ter paciência, uma vez que a natureza impunha-lhe esse castigo [...]. (CAMINHA, 2010, p. 66)

Nas narrativas dos professores, objeto de análise deste estudo, foi possivel evidenciar fragmentos que remetem a tais questionamentos, com forte presença do sentimento de culpa, pelo menos num dado momento das suas trajetórias. Ressalta o professor Logun Edé: “Teve momentos em que eu me perguntava: Meu Deus por que eu? O fato de não se sentir parte da coisa, ou seja, da norma, levantava esses questionamentos em mim. Lembro que pedia a Deus para gostar de mulher". Nessa mesma perspectiva, o professor Obá lembra que: "[...] em certos momentos da minha adolescência eu ficava me perguntando se essas coisas que eu sentia não era uma doença, porque é isso que pregam em casa, na escola e em todo lugar. Ser gay era algo associado a loucura ou doença".

Nos excertos apresentados acima, tanto na narrativa literária acerca do Bom-Crioulo, quanto dos professores Logun Edé e Obá, é perceptivel a concepção sociocultural a respeito da heterossexualidade compulsória, que acaba por impor o binarismo sexual como sendo a única possibilidade no tocante à orientação sexual. o que destoa de tal norma será classificado como estranhx, atribuído à ideia de patologia e/ou transtorno psiquiátrico. Sobre isso o professor lansã pontua que:

Poderia ficar aqui um dia todo contigo e mesmo assim não seria o suficiente para narrar o quanto gays, lésbicas, travestis e pessoas trans sofrem diariamente, se bem que tu sabe [...]. 0 fato de ser viado nos leva a sermos comparados com aquelas categorias mais excluídas socialmente, como: loucos, usuários de drogas, bandidos e por aí vai. [...] sem falar nas agressões que sofremos a todo o momento, as verbais são as mais comuns, mas não estamos livres das agressões físicas não [...]".

No fragmento apresentado pelo professor lansã, é possível perceber que a injúria atribuída àquelxs que rompem a heteronormatividade naturaliza a homofobia e faz com que gays, lésbicas, travestis e trans, vivenciem a experiência dos insultos, dos xingamentos e da agressão física, atribuídos como penalidade àquelxs classificadxs como desviantes. Conforme discute Silva (2017), a violência linguística, enquanto discurso que posiciona o outro no lugar social e político que não se deseja habitar, um lugar abjeto e exposto a várias violações, em geral, em termos de raça, classe, gênero e sexualidade, constitui-se em uma forma de apontar o estranho, uma vez que o corpo se constitui o lócus de manifestação da estranheza, ao tempo em que é interpelado enquanto objeto passível de injúria e castigos físicos, dentre outras formas de violência. 
[...] mas o importante é que estamos aí. Nos xingam? Xingam sim! Mas nós continuaremos existindo. Nos matam? Matam sim! Mas nós continuaremos presentes. Estamos nas ruas e de alguma maneira mexemos nessa estrutura sexista e homofóbica. A forma como me visto, como projeto meu corpo, sim esse corpo considerado estranho, é também um ato de resistência. (PROFESSOR LOGUN EDÉ)

Inferimos, portanto, que, como estratégia de sobrevivência em sistemas compulsórios, o gênero é uma performance com consequências punitivas. Os gêneros estranhos são parte do que "humaniza" os indivíduos na cultura contemporânea, uma vez que habitualmente são punidxs xs que não desempenham corretamente o gênero que lhes foi atribuído, performances de gênero que não citam as normas regulatórias da relação de contiguidade do sistema sexo-gênero-desejo (BUTLER, 2016).

Quando aquilo que faz parte de nossa vida cotidiana se torna problemático e confuso, quando ansiamos usar determinadas coisas e não sabemos como lidar com elas, quando a acepção costumeira das ações, dos valores ou das pessoas, não faz mais sentido, em suma, quando o que nos ensinaram sobre nós e sobre xs outrxs já não nos satisfaz e queremos saber mais e melhor, esse desejo de deslocamento se choca com o fato de que "[...] você aprende que é errado aquilo que você sente, que Deus não gosta, a família não gosta. Você não é igual a seus coleguinhas e isso era um conflito em minha cabeça, eu ficava louquinho" (PROFESSOR OSSAYN). Nisso habita o estranho.

Para o professor Logun Edé, "ser considerado estranho ou ser estranhado nos é tão familiar. Qual é o viado que nunca se sentiu estranho? [...] nos classificam como estranhos quando ainda somos crianças". Ainda segundo ele "[...] Pode acontecer tudo de ruim com você, apenas por você ter um jeito estranho, mas estranho para quem?" Assim, o estranho, mesmo quando habitual, comum, repetido, continua a ser estranhado, e aquilo em que elx acredita também é estranho. Dessa maneira, o procedimento natural se rompe, quando somos capazes de uma postura questionadora perante as coisas e os fatos que nos pareciam familiares. Ainda sobre a estranheza, o professor Logun Edé narrou:

No meu caso foi na passagem entre a infância e a adolescência. Na infância era bonito a gente dançar "É o tchan!5", requebrar, ir até o chão, tá ali brincando de tudo e os adultos justificam que a gente pode brincar porque é coisa de criança, então tudo é "normal". Então vem a adolescência e todos os seus coleguinhas começam a sentir desejos e vai se interessando pelo sexo oposto. E eu olhava e não me dizia nada, não me afetava em nada. E quando menos se espera, lá estava eu estava envolvido num universo carregado de preconceitos, na verdade eu estava num campo minado. Onde poderia ser apedrejado, receber lâmpadas na cabeça. [...]

Na infância, quando a gente começa a se descobrir, mesmo inocente acaba sendo culpado por toda sociedade, nas diferentes dimensões, pura e simplesmente por se gay, mesmo não sabendo o que é ser gay. Interessante isso, eu não sabia o que era ser gay e já diziam que eu era viado. Agora eu percebo que esse estranhamento na infância se deu meramente no campo da sexualidade. Na infância tinha momentos em que eu me sentia estranho e momentos em que eu era tido como estranho. A masturbação, por exemplo, eu ouvia falar e tudo, mas eu não sabia como era, porque na minha casa esses assuntos de sexualidade eram tabus, na escola era tratado com panos quentes e apenas na perspectiva da reprodução que a gente aprende em ciências, e os meninos diziam que pensava nas meninas e ejaculava e para mim não dizia nada.

5 É o Tchan, inicialmente denominado de Gera Samba, grupo brasileiro de pagode/axé, surgido na cidade de Salvador e que se tornou um fenômeno comercial nacional e internacional, na segunda metade da década de 1990. Com diversas canções de teor erótico e duplo sentido, o grupo se popularizou com a ajuda de um trio de dançarinxs. O grupo musical vendeu ao todo, de 1994 a 2007, mais de 6 milhões de álbuns no Brasil. (LEME, 2003) 
Na narrativa do professor Logun Edé, podemos evidenciar que o estranhamento é construído no corpo dx "outrx", a partir de um discurso imbuído pela perspectiva heteronormativa, prevalecendo o imperativo do homem branco, heterossexual, de classe média urbana e cristã, que passa a ser a referência que não precisa mais ser nomeada (LOURO, 2007).

No caso do professor Logun Edé, o estranhamento relacionado à sua orientação sexual só será enfatizado na adolescência, quando algumas brincadeiras e atividades começam a ser demarcadas de forma mais incisiva, como sendo de menino ou de menina, uma vez que “na infância era bonito a gente dançar 'É o tchan!', requebrar, ir até o chão, tá ali brincando". Tais atos são justificados por ser a brincadeira uma atividade inerente ao universo infantil, portanto, considerada pelos adultos que conviveram com esse colaborador em sua infância, uma prática que não possuía maiores conotações em termos de transgressão de normas corporais, de gênero e de sexualidade.

0 estranhamento começa a emergir quando a interpretação de situações, como as narradas, se afasta de um mero modo de brincar, vinculando-se, agora, a um modo de ser articulado a uma sexualidade presumida. Relata ele que: "todos os seus coleguinhas começam a sentir desejos e vai se interessando pelo sexo oposto. E eu olhava e não me dizia nada", continua ele: "E quando menos se espera, lá estava eu envolvido num universo carregado de preconceitos, na verdade eu estava num campo minado. Onde poderia ser apedrejado, receber lâmpadas na cabeça", atitudes designadas às pessoas cujos corpos são significados sob o estigma do estranho.

No caso do professor Logun Edé, o estranhamento acontece mesmo sem ele ter consciência de qual o significado da palavra, em si mesma, e do próprio social que lhe estavam atribuindo, ao nomeá-lo de forma específi- ca, intencionando insultá-lo, uma vez que ele "não sabia o que era ser gay" e mesmo assim "já diziam que eu [ele] era viado".

Num modelo de sociedade heteronormativa, xs "outrxs" sujeitos sociais que se tornarão "marcadxs", que se definirão e serão denominadxs a partir desse imperativo. Por esse prisma, os gays são descritos como desviantes da norma, uma vez que suas atitudes e aparência não condizem com seu sexo, afinal de contas são corpos masculinos que se apresentam com trejeitos femininos, tal como o corpo de Aleixo, parceiro sexual de Amaro, em o Bom-Crioulo. Aleixo é descrito como um prestador de serviços tipicamente feminino, por ter atributos frágeis e afeminados. Ademais, Amaro trata Aleixo como se trata uma mulher. As características que descreve e admira nele são atributos femininos, "Faltavam-lhe os seios para que Aleixo fosse uma verdadeira mulher!... Que beleza de pescoço, que delícia de ombros, que desespero!..." (CAMINHA, 2010, p. 56).

Ao se deparar com esses corpos estranhos, a norma pergunta: como é possivel que homens sejam identificados com o feminino, indo contra a sua natureza e renunciando à posição historicamente privilegiada do homem heterossexual?

Para Oxumaré, o estranhamento é uma marca inerente a todo gay.

Ser estranho é uma marca de todo gay. O tempo inteiro somos apontados como estranhos. No meu caso, o estranhamento se deu principalmente quando eu percebi, e isso foi muito cedo, que eu tinha interesse sexual por meninos e não por meninas. E isso foi muito dificil, porque gostar de meninos era para meninas e eu não era menina, então você passa a viver numa linha muito tênue, onde não é um menino, considerando os padrões estabelecidos, mas também não é uma menina, então não sendo isso, nem sendo aquilo, visto que na nossa sociedade só se é isso ou aquilo, você passa a ser classificado como estranho, ainda na infância, como se eu tivesse culpa de gostar de meninos 
e não de meninas. Não é nem diferente, o diferente é o que sendo daquele grupo tem diferenças, nesse caso o estranho chega a ser algo que te coloca num lugar que nem classificado pode ser. E isso é muito complicado para uma criança ou adolescente quando começa a descobrir a sexualidade.

Gostar de meninos, onde todos os seus colegas eram meninos, então imagine conviver com pessoas que você não "deveria", mas tem desejo sexual e eu tive que camuflar isso o tempo inteiro, o que só me tornava ainda mais estranho. Não gostar de meninas ou de coisas teoricamente associados ao universo masculino me colocava no lugar de estranho para os outros, mas ter que camuflar isso o tempo inteiro me colocava num lugar de estranhamento para mim mesmo. Como não expressar algo que era tão bonito em mim, que era o desejo de ficar com alguém que eu estava gostando? Isso era muito estranho. Então me classificavam como estranho considerando normas sociais e eu me via como estranho tendo que seguir essas normas, sabe como é? (PROFESSOR OXUMARÉ)

Aquelxs que não se percebem dentro dos padrões e estereótipos de gênero sofrem com inúmeras retaliações em nome de uma suposta normatividade desde a mais tenra idade e o "tempo inteiro somos apontados como estranhos": em casa, na escola, na rua. Para Oxumaré, ser estranho é viver numa linha tênue, pois a estranheza tira o menino desse lugar social e culturalmente construído para a masculinidade hegemônica, deixando-o deslocado, uma vez que "não sendo isso, nem sendo aquilo, visto que na nossa sociedade só se é isso ou aquilo, você passa a ser classificado como estranho, ainda na infância". Aqui, ser estranho não é apenas ser diferente, é mais que isso. De acordo com o professor Oxumaré é ser colocado "num lugar que nem classificado pode ser".

o "estranho", portanto, passa a ser aquelx que não se submete completamente às normas de gênero e sexualidade e que, com isso, desestabiliza modelos estáticos com a sua capacidade de metamorfose, que pode cambiar entre o masculino e feminino. Por outro lado, ao ser concebido como estranho, o gay coloca a masculinidade em questão, suscitando questionamento de que a mesma não se sustenta como realidade essencial, natural, por assim dizer, abrindo brechas para os ditos estranhos, e desse modo se constitui num espaço de contradição, para a normalidade.

Em linhas gerais, as narrativas têm sinalizado que o final da infância e o decorrer da adolescência tem se constituído enquanto um momento crucial, pois os sujeitos, além de terem de lidar com as descobertas inerentes a essa fase, para os gays existe ainda uma série de inquietações e questionamentos envolvendo a própria sexualidade, conforme nos relatou o professor Ossayn:

Foi na adolescência é que eu percebi, entre 12, 13 anos essa coisa de ser estranho, do ser diferente em relação aos meninos. Porque eles começavam a falar em namoro, em namorar com meninas e eu me sentia alheio a tudo aqui, me sentia diferente, mas não sei se por pressões, mas eu também acabava entrando na onda e namorava com meninas, ficava com meninas, o que também era estranho. Era uma forma de aceitação, já que eu queria ser aceito pelo grupo, então eu tive que passar por isso aí. Mas desde quando era criança eu já sentia que eu era diferente, que eu fugia da regra, não me enquadrava no universo considerado como sendo dos meninos em relação a sexualidade, a atração com relação as meninas, eu já me sentia diferente. Interessante como só depois é que a gente vai se dar conta que a gente era diferente. Os trejeitos que eu tenho me acompanham desde a infância e ter trejeitos é sinônimo de ser diferente.

[...]. Você fica receoso de muita coisa. Receoso na forma de falar, para não ser muito afeminado, do que e como brincar, do que vestir, como andar - eu lembro de querer andar durinho, como se diz que homem anda e de querer pertencer a esse grupo dos normais. Mas eu gostava mesmo era de vestir roupas femininas, usava muitas roupas das minhas irmãs, mas tudo isso era escondido, até porque eu já estava na adolescência. 
Foi justamente na adolescência que comecei a perceber mais esse estranhamento, mas eu já me entendia, eu já sabia que eu era gay desde criança eu já sabia que era gay, mas ter coragem para se relacionar e para dizer que é na adolescência, eu achava muito dificil você dar a cara a tapa você tão jovem assim, mas eu já me percebia gay desde sempre, desde criança. Esse estranhamento se deu muito por conta do fato de que eu gostava de brincar com as meninas da rua, minhas vizinhas. Eu não me sentia diferentes brincando com elas e acho que elas também não, era como se eu fosse uma menina também, mas até então... como posso dizer? É...eu não me sentia estranho, eu era estranho em relação aos meninos. Eu requebrava muito, tinha toda uma sensibilidade, isso que a gente chama de sensibilidade gay, naquela época eu já tinha. Eu fui viada desde sempre.

$\mathrm{Na}$ narrativa do professor Ossayn, é perceptivel que o estranhamento perpassa de certa maneira pelo restringir-se e limitar-se, uma vez que ele ficava receoso ao desenvolver atividades corriqueiras, como por exemplo, falar, brincar, vestir, andar "para não ser muito afeminado". Ser estranho, nesse sentido, diz respeito à anulação de uma parte da pessoa, da sua própria vida enquanto sujeito.

Ao contar que requebrava muito e que tinha toda uma sensibilidade, classificado por ele como "sensibilidade gay", o professor Ossayn transgride regras, colocando-se num lugar de estranhamentos, vez que a ele são impostas mutilações subjetivas que tendem a impedir a revelação do segredo para as pessoas do convívio pessoal e social como um todo. Tanto é assim que o perceber-se gay, assumir-se gay, em geral, é um processo lento, onde, muitas vezes, faz-se necessário buscar estratégias de sobrevivência, entrar no jogo e jogar com as regras estabelecidas, para só depois "dar a cara a tapa".

Além dos conflitos internos vivenciados no período da infância e da adolescência, causados pela introjeção de padrões comportamen- tais compulsórios, pautados pela masculinidade e feminilidade hegemônicas, ser classificado como estranho, pelo fato de ser gay, durante a vida escolar, pode ocasionar situações bastante constrangedoras, a exemplo dos não raros casos de discriminação, perseguição, assédio moral, violência simbólica, linguística e até física. De acordo com o professor Obá, a experiência de estranhamento ficou mais nítida nas suas vivências do ambiente escolar:

[...] na escola eu sempre me senti estranho, por mais que eu gostasse desse ambiente escolar, mas era exatamente esse ambiente que me fazia me sentir estranho ao mesmo tempo em que me acolhia. A escola sempre me fascinou, mas também foi onde sofri os piores traumas, não só com relação a sexualidade, mas também as questões raciais ou talvez as pessoas se utilizassem do fato de ser negro para me discriminar sexualmente também. Então, como se não bastasse ser negro, eu ainda era gay. Quando era criança, meu cabelo foi um problema para mim. Meu irmão tem o cabelo liso e o meu é crespo. Eu lembro que as professoras puxavam meus cabelos, tinha que cortar para sumir a ondulação ou quando chegava na escola elas penteavam. Eu chegava na escola com o cabelo cacheadinho, mas entrava na sala com o cabelo assanhado, porque elas penteavam meus cabelos na entrada.

Lembro bem de uma cena com a professora [...], que foi ela abrir meu cabelo, me levar para frente da sala, me expondo junto aos meus colegas e dizia: "eu vou ensinar a sua mãe a botar detefon em seu cabelo, porque deve ter até escorpião dentro dele. Corte esse cabelo que isso não é cabelo de homem". E ela fez esse tipo de exposição algumas vezes e sempre associando elementos da minha negritude aos meus trejeitos de gay.

Tem outro fato que eu também lembro com muita nitidez, por ter uma voz muito doce, que se aproximava muito mais do tom de voz das meninas e, quando aquela professora que falei se aposentou e a gente escreveu uma carta se despedindo dela e, outra professora leu minha carta, me imitava na frente de todos os colegas da sala. Ela fez chacota de minha carta, usou 
uma voz bem fina, para dizer que eu tinha a voz doce, ou seja, de mulher, e ainda desmunhecava e requebrava e os colegas riam e eu sem entender muito porque ela estava fazendo aquilo. Anos depois que a ficha caiu, né. Acorda viado! Então, assim, na escola, eu sempre fui visto como um estranho. Fosse pelo meu jeito, ou meus trejeitos, minha voz, meu corpo, minhas relações, as brincadeiras. De alguma maneira todo meu ser desestabilizava o espaço escolar, entende? Era como se dissessem: "esse lugar não é para você" ou então: "para permanecer aqui você tem que mudar". Tem lugar mais homogêneo que a escola? A farda, a disposição das cadeiras, as filas, tudo isso é nada mais nada menos para colocar todo mundo dentro da norma, mas eu não cabia dentro da norma. Meu corpo não se adequava, meus cabelos também. E não era só eu, era eu e meu irmão. Era como se a escola tivesse falhado e admitir que falhou é tudo que a escola não queria. Então, o jeito era dizer que eu é que era estranho.

A experiência de estranhamento do professor Obá nos faz perceber que a escola, enquanto instituição educativa, se estrutura a partir de discursos que reverberam em dizeres e fazeres cotidianos fortemente subordinados a um conjunto dinâmico de valores, normas e crenças, responsável por reduzir à figura $d x$ "outrx", tidx como estranhx, inferior, pervertidx ou contagiosx, todxs aquelxs que não se adequarem ao único modelo reconhecido pela heteronormatividade e pelos arsenais multifacetados a ela ligados. De acordo com Louro (2000, p. 6):

[...] Os sujeitos que, por alguma razão ou circunstância, escapam da norma e promovem uma descontinuidade na sequência sexo/gênero/sexualidade serão tomados como minoria e serão colocados à margem das preocupações de um currículo ou de uma educação que se pretenda para a maioria.

O problema da sexualidade converte-se na descrição de modos de produção de corpos, histórias e identidades, a partir das categorias de um discurso social fortemente normativo na e pela educação. Dessa forma, a vivência de sexualidades não normativas, a possibilidade de considerar $x$ outrx na sua condição de estranhx, assumindo a estranheza enquanto elemento positivo nos espaços de produção e reprodução de conhecimento, tem a ver com a compreensão dos processos e contextos históricos que propiciaram sua construção.

Da concepção de diversidade à compreensão da linguagem como um recurso semiótico que constrói x outrx, a estranheza se inscreve a partir da construção social e histórica do discernimento sobre esse ideal do "normal". Para o professor lansã:

Isso de ser estranho é algo que me persegue, mesmo tendo consciência de ter que defender minha sexualidade, minha identidade de gênero, mas ainda tem algumas coisas que as pessoas acham estranhas em mim e de certa forma até eu acho. Tem momentos em que a gente volta à estaca zero e se percebe refletindo. Inclusive o fato de transitar enquanto pessoa andrógena, era justamente por isso. Então quando estava bem comigo mesmo, quando queria me libertar de todas as amarras eu dizia: “Não estou nem aí para ninguém, não estou nem aí para a família, eu quero é ser feliz". Então ia para rua, comprava minhas roupas coloridas, nunca usei saia, nem vestido e salto, sempre tive receio, mas comprava sapato feminino, sapatilhas, blusa feminina, calça feminina, me maquiava, mas quando vinha aquele momento depressivo, em que as pessoas acentuavam demais que eu era estranho, das barras do dia a dia, a cobrança para ser normal, principalmente por parte da família.

A partir da narrativa do professor lansã, podemos perceber que a estranheza não se dá em um momento estanque da vida daquele que é gay, sendo possivel demarcar a infância como um momento inicial, perdurando por a toda vida, conforme relatou o professor lansã: "[...] ser estanho é algo que me persegue".

A estranheza em conceber as diferentes sexualidades que esquivam da norma heterossexual como estranhas, tendo por base pres- 
supostos biológicos, não é apenas um equívoco, mas a comprovação da imposição de uma "eloquente grade cultural sobre uma natureza que, em si mesma, é - culturalmente falando silenciosa" (SILVA, 2011, p. 145).

Quando a diferença se configura enquanto contraponto daquilo que está dentro da norma, consequentemente, constituindo a norma, ao mesmo tempo em que se faz marginal, por não caber no espaço da norma, as diferentes sexualidades têm se tornado, ao longo da história, objeto de estranhamento, discriminação e violência.

De acordo com o professor Oxóssi, não ter um corpo másculo, adequado às normas de masculinidade vigentes, de alguma forma 0 classificou como estranho.

[...]. Isso já era de alguma maneira porque eu sentia esse estranhamento, então eu preferia eliminar qualquer possibilidade de que isso se estendesse, era como se fosse uma defesa contra esse estranhamento. Sim... meu perfil também não era de mulherzinha, de andar rebolando, mas não tinha a voz grossa, como a maioria dos meus colegas, então diziam que minha voz era estranha: "Esse menino não vai mudar a voz não? Isso tá estranho!". Sem falar nos trejeitos. Eu tinha e ainda tenho (risos) uns trejeitos que se aproximavam muito do universo feminino e isso naquela época era uma tortura. Hoje não, quem quiser falar que fale, mas essa exposição de comparar voz, trejeitos comparando a uma mulher, naquela época, era terrivel.

Para o professor Oxóssi, a estranheza consiste na aproximação com o universo feminino, a voz fina e os trejeitos que o aproximavam "muito do universo feminino", tornando-se um estranho. De acordo com Foucault (2008), a nossa sociedade transpôs o "umbral da modernidade biológica", na passagem do século XVIII para o XIX, exatamente por serem os corpos humanos o centro das estratégias políticas do poder disciplinar, as quais se deram por meio do controle biológico, incluindo as práti- cas sexuais. Nesse contexto, o corpo tem sido alvo de rótulos discursivos e objeto de disciplinarização e controle.

As narrativas dos professores evidenciam que o estranho é produzido em seus corpos a partir do momento em que esses, de alguma maneira, se aproximam simbolicamente do corpo lido como feminino. 0 estranho, portanto, é o aproximar-se de um universo considerado inferior pelo prisma heteronormativo. Assim, a estranheza é um sentimento absorto. E, no entanto, camuflado, uma vez que consiste no desvelamento daquilo que $x$ outrx é, com o intuito de encobrimento daquilo que se é de fato.

Nesse sentido, tanto as narrativas que descrevem o romance entre Amaro e Aleixo em Bom-Crioulo, quanto nas narrativas dos professores, a homossexualidade é associada a uma perspectiva pejorativa, a partir de um processo de subalternização dos personagens homoafetivos, cujo desejo é alijado na e pela sociedade da época e na contemporaneidade, impondo a degradação moral e social aos que subvertem a norma. É possível verificar nas narrativas um mundo de injúrias, designado aos corpos dos personagens homossexuais, objetos de poder e de manipulação.

Para Butler (1999, p. 154), o sexo como norma regulatória proporciona sua materialização no corpo, produzindo "[...] a diferença sexual a serviço da consolidação do imperativo heterossexual". Assim, as normas regulatórias do sexo também funcionam através da repetição e reiteração constantes das normas do gênero assentadas na heterossexualidade compulsória (LOURO, 2001). A norma, constituidora da identidade heterossexual, sente-se ameaçada pelos abjetos que ela mesma cria e o processo de homogeneização se vê atravessado e desestabilizado pela estranheza dos professores.

Os estudos queer, ao suscitarem a possibilidade de desalinhar a configuração normati- 
va das identidades, ao tempo em que fazem emergir questões concernentes ao poder, resistência e transgressão, constituem-se ainda enquanto possibilidade radical de resposta às sexualidades tomadas como subalternas, no sentido reconstruir as políticas de equidade que ainda se ancoram em categorias que se originam em matrizes heteronormativas.

0 termo queer pode ser traduzido como estranho, excêntrico, raro, extraordinário, ridículo. Ele passa a ser utilizado por um grupo de teóricxs (FOUCAULT, 2010; BUTLER, 2014; SILVA, 2011; LOURO, 2007), que pensam as questões de gênero e sexualidade com base em uma perspectiva pós-crítica, com o intuito de suscitar uma reflexão analítica da norma, por meio da sexualidade, passando a analisar como a sexualidade é atravessada por discursos de normalização e, a partir desse campo investigativo, a sexualidade e o desejo serão pensados enquanto relações sociais, culturais e econômicas.

\section{Considerações finais: 0 estranhamento não é o fim}

As narrativas analisadas nesse estudo, nos possibilitaram reverberar que ser estranho, estranhar-se, ser estranhado é um sentimento comum aos gays desde a mais tenra idade. A diferença, estigmatizada posteriormente como estranheza, marca de distintas maneiras o corpo gay.

Pesquisar sobre gênero e diversidade sexual ainda se constitui um desafio, especialmente se pensarmos por meio da concepção desestabilizadora e seus efeitos na sociedade. Um desafio tanto para aquelx que colabora com a pesquisa, quanto por parte daquelxs que pesquisam as questões inerentes a essas temáticas, já que, além de todo o caráter transformador que um estudo com essa dimensão pode assumir, entendemos que o mesmo con- tribui significativamente no que se refere à problematização de tais temáticas, tanto nos espaços internos da comunidade acadêmica quanto nos sociais.

Contudo, consideramos importante ressaltar que individualmente também fomos afetadxs, no sentido positivo do termo, tanto no que se refere às minhas implicâncias enquanto pesquisador, quanto dos professores que fizeram parte desse estudo, uma vez que podemos afirmar que esse estudo contribuiu para que tenhamos uma expressão mais livre em relação às diferentes maneiras de ser e viver a homossexualidade. Ou, como disse o professor Ossayn, em sua narrativa, “[...] essas pesquisas são necessárias, pois nos ajudam a pensar nossa prática pedagógica enquanto professores gays".

Xs teóricxs dos estudos de gênero e sexualidade que contribuíram na construção desse estudo nos ajudaram a compreender o estranhamento imposto pela escola em relação a estudantes e professores gays como um mecanismo que não se contenta apenas com ocultar a presença desses sujeitos nos processos educativos, mas, ao contrário disso, a escola permanece reverberando discursos e práticas heteronormativas, classificando como estranhos todxs aquelxs que vão de encontro a esse modelo. Por conseguinte, a discriminação e o preconceito contra aquelxs que transgridem esse modelo.

Conforme relatou o professor Oxumaré: "a escola ensinava a ser hetero". A partir desse contexto, podemos inferir que as escolas, por meio do seu currículo, não estão preparadas para promover a dignidade e a cidadania plena de estudantes e professores gays, transexuais, travestis, ou para qualquer outra forma de se viver a sexualidade que não esteja na perspectiva heteronormativa.

Por outro lado, as narrativas também sinalizaram que, mesmo as escolas não estando preparadas para receber de forma cidadã 
pessoas que vivenciam a sexualidade fora dos padrões estabelecidos social e culturalmente, elas ainda podem se configurar enquanto espaço de acolhimento da diferença, ainda que seja à revelia, como nos narrou o professor Obá: "A escola ao mesmo tempo que nos acothe nos expulsa e, penso que permanecer na escola é um ato de rebeldia por parte de nós gays". Nesse sentido, permanecer na escola, ou em qualquer outro espaço ou instituição que nos classifica como estranhos, se configura num ato de rebeldia.

Ademais, por meio das narrativas dos professores Oxumaré, Ossayn, Obá, Logun Edé, Oxóssi e lansã e do aporte teórico utilizado na construção deste estudo, podemos inferir que o estranhamento não é apenas um sentimento comum aos professores gays, antes ele diz respeito a um processo de construção histórica que vai classificando como estranho todxs aquelxs que rompem com um modelo de sexualidade pautado unicamente pela perspectiva heternormativa.

Dessa maneira, entendemos que esse estudo vem ao encontro de tantos outros, ao tempo em que salienta a importância de desenvolvimento e implementação de políticas públicas para o acesso e permanência das diversidades no espaço escolar. Para que isso seja efetivado, entendemos que se faz necessário pensar a matriz curricular da escola a partir de um currículo queer e, principalmente, do que se refere à formação inicial e continuada dxs profissionais de educação.

\section{Referências}

BENJAMIN, Walter. Passagens. Organização da edição brasileira de Willi Bolle; tradução de Irene Aron e Cleonice Paes Barreto Mourão. Belo Horizonte; São Paulo: UFMG; Imprensa Oficial do Estado de São Paulo, 2009.

BUTLER, Judith. Problemas de gênero: feminismo e subversão da identidade. Rio de Janeiro: Civilização Brasileira, 1999.

BUTLER, Judith. Regulações de gênero. Cadernos Pagu, v. 42, p. 249-274, jan./jun. 2014.

BUTLER, Judith. Corpos que pesam: sobre os limites discursivos do sexo. In.: LOURO, Guacira Lopes. (Org.). 0 corpo educado - pedagogias da sexualidade. Belo Horizonte: Autêntica, 2016. p. 151-172.

CAMINHA, Adolfo. Bom-Crioulo. São Paulo Martin Claret, 2010.

FOUCAULT, Michel. Vigiar e punir: nascimento da prisão. Tradução de Raquel Ramalhete. Petrópolis, RJ: Vozes, 2008.

FOUCAULT, Michel. História da sexualidade: a vontade de saber. Rio de Janeiro, Graal, 2010.

GAMSON, Joshua. ¿Deven autodestruirse los movimientos identitários? Un extraño dilema. In: JIMÉNEZ, Rafael M. Mérida. (Ed.). Sexualidades transgresoras: una antología de estudios queer. Barcelona: Icaria, 2007. p. 141-172.

JOSSO, M. C. Experiências de vida e formação. São Paulo: Cortez, 2010.

LEME, Mônica Neves. Que 'Tchan' é esse? Indústria e produção musical no Brasil dos anos 90 . São Paulo: Annablume, 2003.

LOURO, Guacira Lopes. Currículo, género e sexualidade. Porto: Porto Editora, 2000.

LOURO, Guacira Lopes. Um corpo estranho: ensaios sobre sexualidade e teoria queer. Belo Horizonte: Autêntica, 2001.

LOURO, Guacira Lopes. Gênero, sexualidade e educação. Uma perspectiva pós-estruturalista. Petrópolis, RJ: Vozes. 2007.

MIGUEL-PEREIRA, Lúcia. Adolfo Caminha - Trechos escolhidos. Rio de Janeiro: Agir, 1960.

PARAÍSO, Marlucy. Um currículo entre formas e forças. Educação, Porto Alegre, v. 38, n. 1, p. 49-58, jan./ abr. 2015.

ROLOFF, Aion et al. O uso do " $x$ " como marca de gê- 
nero no facebook ${ }^{\circledR}$ : uma análise sociolinguística. Revista Versalete, Curitiba, v. 3, n. 4, ja n. / jun. 2015. Disponível em: http://www.revistaversalete. ufpr.br/edicoes/vol3-04/26AionRoloff.pdf. Acesso em 20 dez. 2018.

SILVA, Tomaz Tadeu da. Documentos de identidade: uma introdução às teorias do currículo. Belo Horizonte: Autêntica, 2011.

SILVA, Danillo da Conceição Pereira. Uma política das vidas (in)viáveis: reflexões sobre performatividade e violência transfóbica no discurso. In: SILVA, Danillo da Conceição Pereira; CASTRO, Lorena Gomes de.; MELO, Iran Ferreira de. (Orgs.). Dissidência sexuais e de gênero nos estudos do discurso. Aracaju: Editora Criação, 2017. p. 47-67.

SOUZA, Elizeu Clementino de. A arte de contar e trocar experiências: reflexões teórico- metodológicas sobre história de vida em formação. Revista Edu- cação em Questão, Natal, v. 25, n. 11, p. 22-39, jan./ abr. 2006.

TILIO, Rogério. o jogo discursivo na vida afetiva: a construção de masculinidades hegemônicas e subalternas. In: LOPES, Luiz Paulo da Moita. (Org.) Discursos de identidades: discurso como espaço de construção de gênero, sexualidade, raça, idade e profissão na escola e na família. Campinas, SP: Mercado de Letras, 2003. p. 89-111.

TREVISAN, João Silvério. Introdução à obra BomCrioulo, de Adolfo Caminha. São Paulo: Hedra, 2009.

VELLOSO, Mônica Pimenta. A literatura como espelho da nação. Estudos Históricos, Rio de Janeiro, v. 1, n. 2, p. 239-263, 1988.

Recebido em: 16/04/2019

Aprovado em: 02/06/2019

Pedro Paulo Souza Rios Doutor em Educação pela Universidade Federal de Sergipe - UFS; Mestrado em Educação, Cultura e Territórios Semiáridos - UNEB; Coordenador do Grupo de Estudos e Pesquisa em Educação, Gênero e Sexualidades do Sertão - GENESES-Sertão; Professor da Universidade do Estado da Bahia - UNEB, Campus VII. e-mail: peudesouza@yahoo.com.br

Rua São Felipe, 109 - Populares - CEP: 48.970-000 Senhor do Bonfim - Bahia

Telefone: (74) 99141-3251

Alfrancio Ferreira Dias Doutor em Sociologia. Professor Adjunto II do Departamento de Educação - DEDI e Coordenador do Programa de Pós-Graduação em Educação - PPGED da Universidade Federal de Sergipe. e-mail: diasalfrancio@ gmail.com

Rua Fátima Maria Chagas, 480 - Cond. Bellagio Residence, Bloco 2, Apart. 106.

Bairro Jabutiana - Aracaju - SE CEP: 49.095-793 